\title{
Analysis of genetic susceptibility to mercury contamination evaluated through molecular biomarkers in at-risk Amazon Amerindian populations
}

\author{
Maria de Nazare Klautau-Guimarães ${ }^{1}$, Renata D’Ascenção ${ }^{1}$, Fabiana A. Caldart ${ }^{1}$, Cesar K. Grisolia ${ }^{1}$, \\ Jurandir R. de Souza ${ }^{2}$, Antonio C. Barbosa ${ }^{3}$, Célia M.T. Cordeiro ${ }^{4}$ and Iris Ferrari ${ }^{1}$ \\ ${ }^{1}$ Universidade de Brasília, Instituto de Ciências Biológicas, Departamento de Genética \\ e Morfologia, Brasilia, DF, Brazil. \\ ${ }^{2}$ Universidade de Brasília, Instituto de Química, Brasília, DF, Brazil. \\ ${ }^{3}$ Instituto Brasileiro do Meio Ambiente, Setor de Áreas Isoladas Norte, Brasília, DF, Brazil. \\ ${ }^{4}$ Embrapa/Cenargen, Centro Nacional de Pesquisa de Recursos Genéticos e Biotecnologia, \\ Brasilia, DF, Brazil.
}

\begin{abstract}
We investigated Individual differences in susceptibility to methylmercury (MeHg) contamination and its relationship with polymorphisms of the detoxifying enzyme glutathione S-transferase (GST). In Brazil, some Amerindian tribes from the Amazon region have an increased level of mercury in their hair. Samples of hair and blood were taken from inhabitants of two villages in the Kayabi and Munduruku Amerindian communities to investigate mercury levels in association with genetic polymorphism of GSTs. Other molecular biological markers were also studied, such as hemoglobin, haptoglobin and glucose 6-phosphate dehydrogenase (G-6-PDH). Higher levels of mercury contamination were found in the Kayabi villagers, who had a null genotype (GSTM1 0/0, also denominated GSTM1 null) frequency of $26 \%$, than in the Munduruku villagers, for which the null genotype frequency was $0 \%$. Individuals with the GSTM1 null phenotype had higher concentrations of mercury in their hair than individuals with GSTM1+/+ phenotypes $(F=21.51, p<0.0001)$. No association with other markers studied was observed. This study suggests that GSTM1 may be involved in the biotransformation of mercury in humans.
\end{abstract}

Key words: Amerindian, genetic polymorphism, glutathione S-transferase, mercury.

Received: May 21, 2004; Accepted: May 4, 2005.

\section{Introduction}

Mercury, a naturally occurring element that is released from a variety of sources including human activity, is used industrially all over the world because of its diverse properties. In the Brazilian Amazon, mercury contamination of fish can occur as a result of both natural biogeochemical processes and gold-mining activities (Pfeiffer and Lacerda, 1988; Eve et al., 1996; Lechler et al., 2000). Human mercury contamination results primarily from fish consumption because fish not only absorb methylmercury $(\mathrm{MeHg})$ from the water throughout their life but also convert inorganic $\mathrm{Hg}^{+2}$ to methylmercury through biomethylation occurring in their body. Fish at the top of a food chain

Send correspondence to Cesar Koppe Grisolia. Universidade de Brasília, Instituto de Ciências Biológicas, Departamento de Genética e Morfologia, 70.910-900 Brasilia, DF, Brazil. E-mail: grisolia@ unb.br. have the greatest accumulation of methylmercury (Barbosa et al., 1995; Shoeny, 1996; Ashner, 2002). In the Brazilian Amazon, many studies have already been carried out on riverine and Amerindian populations to investigate the health impacts of mercury exposure in different communities (Akagi et al., 1995; Barbosa et al., 1998; Boischio and Henshel, 2000; Santos et al., 2000; Dolbec et al., 2001; Dorea, 2003).

Various factors affect the absorption, distribution, biotransformation, excretion and, consequently, toxicity of methylmercury. It has been pointed out (Doi, 1991) that genetically determined factors play an important role in the differential susceptibility which individuals show to mercury toxicity. It is known reduced glutathione (GSH) and $\gamma$-glutamyl transpeptidase $(\gamma$-GT) are involved in the disposition and excretion of methylmercury (Strange at al., 2001), and since glucose-6-phosphate dehydrogenase (G-6-PDH) is involved in the production of GSH a defi- 
ciency in G-6-PDH can influence the metabolism and detoxification of mercury (Harris 1980). Methylmercury is exported from liver cells into plasma in complex with GSH because both inorganic and methylmercury have high affinity for reduced sulfhydryl ( $\mathrm{SH}$ ) groups, which bind to biological thiols such as L-cysteine and glutathione to form conjugated complexes. Hepatic methylmercury uptake is increased in the presence of plasma cysteine or GSH and some hemoglobin molecules have extra cysteine moieties or cysteine-SH groups which are more accessible to methylmercury, such compositional and structural differences in hemoglobin being genetically determined and correlated with differences in mercury blood levels (Tsuguyouski et al., 1991).

The glutathione S-transferase (GST) gene family is involved in the detoxification of electrophilic compounds by conjugation, and in higher organisms at least five GSTs gene classes (alpha, mu, pi, theta and zeta) have been well studied. Each GST class has substrate selectivity depending on the chemical properties of the compounds. The GSH conjugated is more water soluble and therefore immediately excreted via the bile or urine (Armstrong, 1990; Strange et al., 2001). Naganuma et al (1990) and Choi et al (1996) have shown that GSH deficiency is associated with sensitivity to both mercury chloride and methylmercury. In vitro studies have demonstrated conjugation between methylmercury and GSH to form a complex which can interact with GST-pi, such binding possibly having a protective function against heavy metals (Almar and Dierickx, 1990). According to Brambila et al (2002) various GST genes are activated in rats exposed to mercury, indicating that individuals with specific genotypes could be better protected against the cytotoxicity of methylmercury. In GST $m u$ (GSTM) five $m u$ classes occur in tandem (GSTM4-GSTM2-GSTM1-GSTM5-GSTM3) in a cluster on chromosome 1p13.3. Polymorphism of the M1 locus has been widely described. Homozygotes, in which both GSTM1*0 alleles are deleted (GSTM1 null genotype), do not express the GST protein (Xu et al., 1998). With the GST theta (GSTT), two genes (GSTT1 and GSTT2) are located on chromosome 22 and separated by about $50 \mathrm{~kb}$. The allele GSTT1*0 is also nonfunctional (Coggan et al., 1998). The GST pi (GSTP) are located on chromosome $11 \mathrm{p} 13$ and two different alleles (GSTP1 and GSTP2) have been identified. The wild-type allele differe to the mutant allele by a nucleotide transition on codon 105 of exon 5, which causes in an amino-acid substitution of isoleucine for valine. The mutant that the enzyme ( $\mathrm{val}^{105}$ ) is 3-fold less effective (Harris et al., 1998).

Some Brazilian Amerindian populations use fish as their main dietary protein source and are thought to be contaminated by mercury. We studied the Kayabi and Munduruku Brazilian Amazonian Amerindian communities for mercury contamination and genetic polymorphism in spe- cific biological markers associated with mercury metabolism. The connection between polymorphic genes linked to mercury metabolism and the concentration of mercury in hair was also investigated. This study was carried out on loci for hemoglobin, haptoglobin (Hp), glucose-6-phosphate dehydrogenase (G-6-PDH) and the glutathione Stransferase loci $m u$ (GSTM1), pi (GSTP1) and theta (GSTT1).

\section{Material and Methods}

\section{Study area and communities}

The Kayabi community has an estimated population of 1,000 Amerindians and is situated at $11^{\circ} 37^{\prime} \mathrm{S}$ and $55^{\circ} 40^{\prime} \mathrm{W}$ on the banks of the Teles Pires river which has received high emissions of inorganic mercury from the many gold-mining sites which function along its small tributaries. We sampled 65 Kayabi individuals (41\% males, 59\% females) with an average age of $24.53 \pm 15.57$ years, Table 1 showing the age classes for our sample population. One blood sample was taken from each individual for analyses of gene polymorphisms. The Munduruku community has an estimated population of 646 Amerindians and is situated at $7^{\circ} 37^{\prime} \mathrm{S}$ and $57^{\circ} 34^{\prime} \mathrm{W}$ on the banks of the Teles Pires river, which has received similar mercury contamination. We sampled 117 Munduruku individuals (41\% males, 59\% females) with an average age of $30.90 \pm 15.14$ years, Table 1 showing the age classes for our sample population. One blood sample was taken from each individual for analyses of gene polymorphisms.

Both communities are situated in areas of intensive gold prospecting activity and the main diet of the community is fish and starchy root crops, principally cassava (Manihot ssp.) flour. This study was approved by the ethics committee of the University of Brasília in accordance with the rules of the Brazilian Ministry of Health. All individuals participating in the study, or their legal guardians, provided informed consent.

Table 1 - Mercury levels in hair from individuals from the Kayabi and Munduruku communities

\begin{tabular}{lccc}
\hline Community & $\begin{array}{c}\text { Age class } \\
\text { (years) }\end{array}$ & $\begin{array}{c}\text { Number of indi- } \\
\text { viduals per age } \\
\text { class (\%) }\end{array}$ & $\begin{array}{c}\text { Mean mercury } \\
\text { concentration in } \\
\text { hair (ppm) }\end{array}$ \\
\hline Kayabi & Birth to 20 & $33(50)$ & $17.86 \pm 9.82$ \\
& 21 to 40 & $25(39)$ & $11.97 \pm 6.83$ \\
& 41 to 60 & $5(8)$ & $14.35 \pm 6.70$ \\
Munduruku & $>61$ & $2(5)$ & $15.17 \pm 7.13$ \\
& Birth -20 & $34(29)$ & $4.26 \pm 2.16$ \\
& 21 to 40 & $56(48)$ & $3.65 \pm 1.88$ \\
& 41 to 60 & $20(17)$ & $3.75 \pm 1.67$ \\
& $>61$ & $7(6)$ & $3.72 \pm 2.05$ \\
\hline
\end{tabular}

${ }^{\text {a }}$ Rounded, may not add up to $100 \%$. 


\section{Mercury analysis}

For mercury analysis about 10 hairs (10-20 mg) were weighed on an analytical balance (Mettler AE200, Hightstown, NJ) and placed into separate vials which had been previously weighed and labeled. For digestion, $2 \mathrm{~mL}$ of $45 \% \mathrm{NaOH}, 1 \mathrm{~mL}$ of $1 \%$ cysteine and $5 \mathrm{~mL}$ of $1 \% \mathrm{NaCl}$ (all $\% \mathrm{w} / \mathrm{v}$ ) was added to each vial and the hair digested on a hot plate at $90-95{ }^{\circ} \mathrm{C}$ for $15 \mathrm{~min}$, after which the samples were cooled in crushed ice and any evaporated water replaced. The samples were analyzed for mercury content according to the method of Magos and Clackson (1972) using atomic cold vapor absorption spectrophotometry (CV-AAS) using a model 1255 LDC Analytical Mercury Monitor (LDC, Riviera Beach, Fl, USA) having a quantification limit for mercury of $1.5 \mathrm{ppb}$. The University of Brasilia laboratory is a participant in the Mercury Quality Assurance Program (Hair Mercury-Inter-laboratory Comparison Program, Ottawa, Ontario, Canada).

\section{Gene polymorphism studies}

Individual blood samples were screened for hemoglobin variants using 14\% (w/v) starch gel electrophoresis from hemolisates and haptoglobin $(\mathrm{Hp})$ gel electrophoresis were carried out with serum samples directly (Ramalho, 1986). For G-6-DP variants analysis, agarose gel electrophoresis were carried out from hemolisates (Harris, 1978). Polymorphism of the GST gene family was determined in DNA extracted from each blood samples using a standard method (GFX Genomic Blood DNA Purification Kit Amersham Biosciences), followed by PCR amplification using specific primers for GSTM1 (Fryer et al., 1993), GSTT1 (Kemples et al., 1996) and GSTP1 locus 105 (Park et al., 1999), $\alpha$-globin primers being used as the positive control to check PCR performance. The PCR products were separated using $6 \%$ polyacrylamide gel electrophoresis and visualized by silver nitrate staining.

\section{Statistic analyses}

The allelic and genotype frequencies of both populations were analysed using the chi-squared test $\left(\chi^{2}\right)$ con- tained in the FREGEM - GENIOC statistical package (Cabello and Krieger 1997). The SAS statistical package version 6 was used to perform analysis of variance (ANOVA) and detect associations between different mercury concentrations in the hair samples, specific genotypes, sex and age.

\section{Results}

In our study we found that the mean level of mercury in hair from the Kayabi population was $14.75 \pm 1.0 \mathrm{ppm}$, Table 1 showing the mercury levels for the different age classes. There was no statistically significant differences in hair mercury between the sexes in either community (ANOVA, $p>0.05$ ) but, unexpectedly, there were withinpopulation differences as regards age, with individuals up to the age of 20 being more contaminated than individuals in the 21 to $>61$ age group (Table 1).

Hemoglobin and G-6-PDH analysis showed no variant that could be associated with variability of hair mercury in either population. The haptoglobin $(\mathrm{Hp})$ allele frequencies $\left(\mathrm{Hp}^{*} 1=0.72\right.$ and $\mathrm{Hp}^{* 2}=0.28$ for the Kayabi; $\mathrm{Hp}^{*} 1=0.74$ and Hp*2 $=0.26$ for the Munduruku) in both communities were in Hardy-Weinberg equilibrium (Table 2) and there was no relationship between the distribution of haptoglobin phenotypes and hair mercury contamination according to age or sex (ANOVA, $\mathrm{F}=1.63, \mathrm{p}>0.19$ ).

Glutathione S-transferase M1 (GSTM1) was selected for study based on the hypothesis that the presence or absence of this allele could be associated with the level of mercury contamination. In the Kayabi population $26 \%$ of individuals were homozygous for the non-functional GSTM1 null allele (GSTM1-) but in the Munduruku population all the individuals were monomorphic for the phenotype active GSTM1 (GSTM1+) (Table 3). Individuals with the GSTM1 null phenotype presented (GSTM1-) higher concentrations of hair mercury than GSTM1+ individuals, even considering possible age and sex effects $(\mathrm{F}=21.51$, $\mathrm{p}<0.001$, Table 3). The phenotypic heterogeneity test for GSTM1 polymorphism indicated that Kayabi and Munduruku populations were significantly different $\left(\chi^{2}=34.26\right.$,

Table 2 - Relationship between haptoglobin (Hp) phenotype and mercury levels in the hair of individuals from the Kayabi and Munduruku Amerindian communities.

\begin{tabular}{lcccc}
\hline Community & Phenotype & $\begin{array}{c}\text { Number of individu- } \\
\text { als per age class }(\%)\end{array}$ & $\begin{array}{c}\text { Mean mercury concen- } \\
\text { tration in hair (ppm) }\end{array}$ & Allele frequency \\
\hline Kayabi & Hp1-1 & $34(52.31)$ & $9.59 \pm 0.57$ & 0.72 for Hp* $1^{\text {a }}$ \\
& Hp2-1 & $25(38.46)$ & $9.58 \pm 0.64$ & 0.28 for Hp*2 \\
\hline Munduruku & Hp2-2 & $6(9.23)$ & $6.48 \pm 1.60$ & \\
& Hp1-1 & $59(52.21)$ & $4.26 \pm 2.16$ & 0.74 for Hp* $1^{\mathrm{b}}$ \\
& Hp2-1 & $50(44.25)$ & $3.65 \pm 1.88$ & 0.26 for Hp*2 \\
\hline
\end{tabular}

${ }_{\mathrm{a}} \chi^{2}=0.2$ for $\mathrm{p}>0.8{ }^{\mathrm{b}} \chi^{2}=2.8$ for $0.05<\mathrm{p}<0.10$. 
Table 3 - Phenotypes of GST families with its respective allelic and genotypic frequencies and levels of $\mathrm{Hg}$ in the Kayabi and Munduruks communities.

\begin{tabular}{lccc}
\hline Phenotypes & $\begin{array}{c}\text { Mean mercury } \\
\text { concentration in } \\
\text { hair (ppm) }\end{array}$ & $\begin{array}{c}\text { Allele } \\
\text { frequency }\end{array}$ & $\begin{array}{c}\text { Genotypic } \\
\text { frequency } \\
(\%)\end{array}$ \\
\hline Kayabi community & & & \\
GSTM1+ & $8.2 \pm 0.44$ & 0.49 & 74 \\
GSTM1- & $14.0 \pm 1.36^{\#}$ & 0.51 & 26 \\
GSTTI+ & $9.49 \pm 0.47$ & 0.55 & 80 \\
GSTT1- & $9.29 \pm 0.84$ & 0.45 & 20 \\
GSTP1 ${ }^{\text {Ile/lle }}$ & $14.6 \pm 10$ & GSTP $1 *$ (ile) 57.5 & 38.3 \\
GSTP1 ${ }^{\text {val/val }}$ & $15.0 \pm 10$ & GSTP $1 *$ (val) 42.5 & 23.4 \\
GSTP $1^{\text {Ile/val }}$ & $15.8 \pm 7.9$ & & 38.3 \\
\hline
\end{tabular}

Munduruku community

\begin{tabular}{lccc} 
GSTM1+ & $3.0 \pm 1.2$ & 100 & 100 \\
GSTM1- & $3.24 \pm 0.79$ & 0 & 0 \\
GSTTI+ & $3.64 \pm 0.94$ & 0.50 & 75 \\
GSTT1- & $2.85 \pm 0.82$ & 0.50 & 25 \\
GSTP1 ${ }^{\text {Ile/lle }}$ & $4.26 \pm 2.15$ & GSTP $1{ }^{\text {(ile) }} 67$ & 47.3 \\
GSTP1 $^{\text {val/val }}$ & $3.64 \pm 1.86$ & GSTP $1^{\text {(val) }} 33$ & 13.4 \\
GSTP1 $^{\text {Ile/val }}$ & $3.75 \pm 1.74$ & & 39.3 \\
\hline
\end{tabular}

"Relationship between high hair mercury and the GSTM1 null phenotype significant by ANOVA at $\mathrm{p}<0.001$.

$\mathrm{p}<0.001$, Table 3 . The GSTT1 locus was polymorphic in both populations, with GSTT1 null frequencies of $20 \%$ for the Kayabi sample and $25 \%$ for the Munduruku sample but there was no relationship between the distribution of the GSTT1 null phenotype and mercury contamination $(\mathrm{F}=0.11, \mathrm{p}=0.74)$ and the heterogeneity test for distribution of GSTT1 phenotypes between populations was not significant $\left(\chi^{2}=0.496,0.50<p<0.70\right)$. The results for the GSTT1 and GSTP1 loci were similar, with the GSTP1 locus presenting polymorphism without any relationship being seen between this allele and the level of mercury in either population $(\mathrm{F}=0.15, \mathrm{p}=0.85$, Table 3$)$. The GSTP1 locus showed Hardy-Weinberg equilibrium in both populations $\left(\chi^{2}=2.79 ; 0.05<\mathrm{p}<0.10\right.$ for the Kayabi and $\chi^{2}=1.4$; $0.30<\mathrm{p}<0.50$ for the Munduruku).

\section{Discussion}

In our study, $62.12 \%$ of the Kayabi sample population had a mean hair mercury concentration above the acceptable limit (10 ppm) established by the World Health Organization. Barbosa et al. (1995) demonstrated a direct relationship between dietary habits and mercury contamination in different Amazonian populations and showed that gold prospectors have high levels of mercury in their urine due to occupational exposure to inorganic mercury vapor inhaled during amalgam burning.
When released into the environment, divalent mercury $\left(\mathrm{Hg}^{+2}\right)$ can be converted by sediment bacteria and other organisms into methylmercury $(\mathrm{MeHg})$ which can be bioaccumulated in fish and biomagnified up the food chain. Toxicity of different chemical forms of mercury differs strongly, with $\mathrm{MeHg}$ being among the most potent forms (Potter et al., 1975; Richins et al., 1975; Copper, 1983).

Gene flow between the Kayabi and Munduruku communities is very rare because even though they are vicinal cultural differences act as a barrier to marriages between members of these tribes (Rodrigues, et al., 2002). Rodrigues et al. (2002) reported also that the Munduruku are more isolated and marriage generally occurs within the tribe, while the Kayabi live in an area that has received intensive migration due to gold prospecting and have consequently become somewhat mixed. The differences observed in the GSTM1 gene frequencies between these two communities suggest that they are heterogeneous. We found that $74 \%$ of GSTM1+ phenotype Kayabi sampled had about 8 ppm of mercury in their hair while $26 \%$ of GSTM1 null phenotype Kayabi sampled had mercury levels of $14 \mathrm{ppm}$. On the other hand, all the Munduruku individuals sampled had the GSTM1+ phenotype and low levels of mercury in the hair.

The association between a high frequency of the GSTM1+ allele and lower mercury contamination in the Munduruku sample and the fact that Kayabi GSTM1 null homozygotes had higher levels of mercury than either the GSTM1+ Kayabi or the Munduruku sample suggest that the GSTM1 gene could be involved in mercury metabolism or could be associated with reduced mercury levels. Individual differences in susceptibility to methyl mercury toxicity may be associated with enzymes that exhibit genetic polymorphism. A study by Rodrigues et al. (2002) of 308 individuals from the Munduruku showed almost no mercury contamination (a mean of $4.3 \pm 0.1 \mathrm{ppm}$ ) and our results in the results in table 2 confirm this previous study, showing that the Mundurukus have a lower level of $\mathrm{Hg}$ in their hair.

Both communities appear to have received similar mercury exposure because they have the same dietary habits based on fish and (principally cassava) and are located in areas subject to intensive gold prospecting (Rodrigues et al., 2002). Although the Kayabi community has mercury levels in excess of 10 ppm no clinical signals of mercury contamination have been reported (Rodrigues et al., 2002). Medical practitioners who have followed this community recommended they should eat Brazil nuts (Castanha-dopará), a typical Amazonian nut with a high selenium content which eliminates $\mathrm{Hg}$ from the human body (Imura and Naganura, 1985). Fish per se are the best sources of essential nutrients as well as selenium and are abundant natural resource for the Amazonian Indians and other river-bank dwellers (Dorea, 2003). However, an other study with mercury in the Amazonian ecosystem have shown high con- 
centrations of mercury in fish from the non-polluted freshwater of the Rio Negro which has no history of goldmining (Barbosa et al., 2003). Mercury biomagnification in piscivorous Rio Negro fish appears to be due to pre-formed methyl mercury occurring naturally in the environment and the food-chain of the fish, demonstrating that the mercury cycle in the Amazonian ecosystem is still not well understood (Barbosa et al., 2003).

Our study indicates that some Kayabi individuals with a specific phenotype could have increased mercury load in their body. Genetic variability endows a species with the ability to adapt to the environment over time, because of which it is important to study the role of genetic factors such as GSTM1 polymorphisms in protecting people from mercury damage.

\section{Acknowledgments}

The authors thank the Fundação Nacional do Índio (FUNAI), Deutsche Gesellschaft für Technische Zusammenarbeit (GTZ) and Universidade de Brasília.

\section{References}

Almar MM and Dierickx PJ (1990) In vitro interaction of mercury, copper (II) and cadmium with human glutathione transferase (GST) pi. Res Commun Chem Pathol Pharmacol 69:99-102.

Armstrong RN (1990) Glutathione S-transferases: Reaction mechanism, structure, and function. Chem Res Toxicol 4:131140.

Akagi H, Malm O, Kinjo Y, Harada M, Branches FJP, Pfeiffer WC and Kato H (1995) Methylmercury pollution in the Amazon, Brazil. The Science of Total Environment 1765:85-95.

Aschner M (2002) Neurotoxicity mechanism of fish-borne methylmercury. Environ Toxicol and Pharmacol 12:101-104.

Barbosa AC, Boischio AAP, East GA, Ferrari I, Gonçalves A, Silva PRM and Cruz TME (1995) Mercury contamination in the Brazilian Amazon. Environmental and occupational aspects. Water Air Soil Pollution 80:109-21.

Barbosa AC, Silva SRL and Dórea JG (1998) Concentration of mercury in hair of indigenous mothers and infants from Amazon basin. Arch Environ Contam 34:100-105.

Barbosa AC, Souza JR, Dorea JG, Jardim WF and Fadini PS (2003) Mercury biomagnification in a tropical black water, Rio Negro, Brazil. Environ Contam Toxicol 45:235-246.

Boischio AAP and Henshel D (2000) Fish consumption, fish lore, and mercury pollution - Risk communication for Madeira river people. Environmental Research 84:108-126.

Brambila E, Liu J, Morgan DL, Beliles RP and Waalkes MP (2002) Effect of mercury vapor exposure on metallothionein and glutathione s-transferase gene expression in the kidney of nonpregnant, pregnant and neonatal rats. J Toxicol Environ Health 65:1273-1288.

Cabello PH and Krieger H (1997) Sistema para Análise de dados de Genética. Publicação Técnica, Fundação Instituto Oswaldo Cruz, Rio de Janeiro, 139 pp.

Coggan M, Whitbread L, Whittington A and Board P (1998) Structure and organiszation of the human theta-class gluta- thione S-transferase and D-dopachrome tautomerase gene complex. Biochem J 334:617-623.

Choi HB, Yee S and Robles M (1996) Effects of the glycoside glutathione on the poisoning bby methylmercury. Toxicol and Appl Pharmacol 141:357-364.

Copper JJ (1983) Total mercury in fishes and selected biota in Lahontan reservoir, Nevada: 1981. Bulletin of Environmental Contamination and Toxicology 31:9-17.

Doi R (1991) Individual difference of methylmercury metabolism in animals and its significance in methylmercury toxicity. In: Suzuki T, Imura N and Clarkson TW (eds) Advances in Mercury Toxicology. Plenum Press, New York, pp 145-194.

Dolbec J, Mergler D, Larribe F, Roulet M, Lebel J and Lucotte M (2001) Sequential analysis of hair mercury levels in relation to fish diet of an Amazon population, Brazil. The Science of Total Environment 271:87-97.

Dorea JG (2003) Fish are central in the diet of Amazonian riparians: Should we worry about their mercury concentrations? Environmental Research 92:232-244.

Eve E, Oliveira EF and Eve C (1996) The mercury problem and diets in the Brazilian Amazon: Planing a solution. Found Environ Conserv 23:133-139.

Fryer AA, Zhao L, Alldersea J, Pearson WR and Strange RC (1993) Use of site-directed mutagenesis of allele-specific PCR primers to identify the GSTM1 A,B and GSTM1 null polymorphism at the glutathione S-transferase, GSTM1 1ocus. Biochem J 295:313-315.

Harris H (1980) Handbook of Enzyme Electrophoresis in Human Genetics. Elsevier/North Holland Publishing Co., Amsterdan, pp 123-139.

Harris LW (1978) The principles of human biochemical genetics. In: Handbook of Enzyme Electrophoresis in Human Genetics. Elsevier/North-Holland Publishing Co., Amsterdan, pp 35-174.

Harris MJ, Coggan M, Langton L, Wilson SR and Board PG (1998) Polymorphism of the pi class glutathione S-transferase in normal populations and cancer patients. Pharmacogenetics 8:27-31.

Imura $\mathrm{N}$ and Naganura A (1985) Mode of modifying action of selenite on toxicity and behavior of mercury and other metals. Nutr Res (suppl. 1):499-507.

Kempkes M, Golka K, Reich S, Reckwitz T and Bolt HM (1996) Glutathione S-transferase GSTM1 and GSTM1 null genotypes as potential risk factors for urothelial cancer of the bladder. Arch Toxicol 1-2:123-126.

Lechler PJ, Miller JR, Lacerda LD, Vinson D, Bonzongo JC, Lyons WB and Warwick JJ (2000) Elevated mercury concentrations in soil, sediments, water, and fish of the Madeira River basin, Brazilian Amazon: A function of natural enrichments? The Science of Total Environment 260:87-96.

Magos C and Clackson TW (1972) Atomic absorption determination of total, inorganic and organic mercury in blood. Journal of the Association of Official Analytical Chemists 55:966-967.

Naganuma A, Anderson ME and Meister A (1990) A celular glutathione as a determinant sensitivity to mercury chloride. Prevention of toxicity by giving glutathione monoester. Biochemical Parmacology 40:693-697.

Pfeiffer WC and Lacerda LD (1988) Mercury inputs into the Amazon region. Environ. Technol. Lett 9:325-330. 
Park JY, Schantz SP, Stern JC, Kaur T and Lazarus F (1999) association between glutathione S-transferase pi genetic polymorphism and cancer risk. Parmacogenetics 9:497-504.

Potter L, Kidd D and Standiford D (1975) Mercury levels in Lake Powell - Bioamplification of mercury in man-made desert reservoir. Environmental Science Technology 9:41-46.

Ramalho AC (1986) O laboratório de hemoglobinopatias. In: As Hemoglobinopatias Hereditárias. Revista Brasileira de Genética (eds), pp 129-147.

Richins RT and Risser AC (1975) Total mercury in water sediment and selected aquatic organisms, Carson River, Nevada - 1972. Pesticides Monitoring Journal 9:44-54.

Rodrigues P, Barbosa AC, Ferrari I and Souza, JR (2002) Avaliação da contaminação por mercúrio na terra dos Mundurukss do Pará. In: Demarcando Terras Indígenas II. Deutsche Gesellschaft fur Technische Zusammenarbeit - GTZ (eds), pp 123-148.
Santos EBO, Jesus IM, Brabo ES, Loureiro ECB, Mascarenhas AFS, Weirich J, Câmara VM and Cleary D (2000) Mercury exposure in riverside Amazon communities in Pará, Brazil. Environmental Research 84:100-107.

Shoeny R (1996) Use of genetic toxicology data in U.S. EPA risk assessment: The mercury study report as an example. Environ Health Perspect 104:663-673.

Strange RC, Spiteri MA, Ramachadran S and Fryer AA (2001) Glutathione-S-transferase family of enzymes. Mutation Research 482:21-26.

Tsuguyouski S, Imura N and Clarckson TW (1991) Mercury review. In: Suzuki T, Imura N and Clarkson TW (eds) Advances in Mercury Toxicology. Plenum Press, New York, pp 1-33.

Xu S, Wang Y, Roe B and Pearson WR (1998) Characterization of the human class um glutathione S-transferase gene cluster and GSTM1 deletion. J Biol Chem 273:3517-3527.

Associate Editor: Catarina S. Takahashi 